\title{
The Critical Mass Question, Women Directors and Performance of Banks in Sub Saharan Africa
}

\author{
Anthony Nzeribe Nwaubani \\ Department of Banking \& Finance, Nnamdi Azikiwe University, Awka Nigeria
}

Tel: 234-803-348-4357. E-mail: toninwaubani@yahoo.com

\begin{abstract}
Patience Chioma Orikara
Department of Banking and Finance, Michael Okpara University of Agriculture, Umudike Nigeria
\end{abstract}

Tel: 234-703-443-7956. E-mail: csteveorikara@yahoo.com

$\begin{array}{rrr}\text { Received: December 13, } 2018 \quad \text { Accepted: June 25, } 2019 \quad \text { Published: June xx, } 2019 \\ \text { doi:10.5296/jpmr.v5i1.14985 } & \text { URL: https://doi.org/10.5296/jpmr.v5i1.14985 }\end{array}$

\begin{abstract}
This study mainly evaluated the effect of Board composition on the performance of deposit money banks (DMBs) in Sub Saharan Africa (SSA) with special focus on the critical mass question. Specific objectives are determination of the effect of women directors and board composed of more non-executive directors on return on assets (ROA) and net interest margin (NIM) of the banks. Secondary data on six SSA countries and twelve banks collected for the period 2004 to 2016 were used. Panel data regression approach was employed with model selection subjected to Hausman tests. The study revealed among others that board with more nonexecutive directors has significant positive effect on ROA and NIM with significant positive relationship with ROA and NIM. Women directors have very negligible effect on performance of the DMBs while correlating negatively and insignificantly with ROA and NIM. It is therefore, concluded that though, nonexecutive directors have strong positive significant effect on performance of deposit money banks in Sub Saharan Africa and women directors indicate very negligible effect, the conflicts over the effect of the two variables are not yet fully resolved. It is recommended that DMBs should make room for at least three female directors in their boards while adoption and enforcement of gender quota by countries should be considered.
\end{abstract}

Keywords: group dynamism, tokenism, critical mass, conflict of interest, modern firm 


\section{Introduction}

The Industrial Revolution which started in Britain provided the enabling platform for the emergency of the modern firms in the 1920s (Kapás, 2008). In contract to the modern firm, is the traditional firm which is a single business entity whose entire operations are carried out by an entrepreneur. The main objective of the traditional firm is profit maximization (Jhingan \& Stephen, 2009). The emergence of modern firms with complex structures, divisions and varied objectives necessitated involvement of professional managers and management teams who are separate from the owners but run the firms on behalf of the owners.

Board of directors is a very crucial part of the firm's structure for decision making and implementation of strategies to run the firm and achieve corporate goals of the owners and the various stakeholders. It serves the interests of all stakeholders and exercises leadership, enterprise, integrity and judgment in directing the firm so as to achieve sustainable goals for all stakeholders and thus secure continuing prosperity of the company (Proshare, 2016). The emergency of the modern firm and the consequent separation of management from ownership gave rise to issues of accountability, conflict of interests, protection of the interests of the owners inter alia.

In recent years, celebrated corporate and system failures coupled with dynamic and an increasingly complex regulatory and supervisory environments have turned increasing attention to the need for good governance in corporate entities (McKinsey, 2016). The situation has sharpened the focus on board composition and its effectiveness. Generally the impression is that a board composed of more non-executive/independent directors is more associated with enhanced corporate performance. Code of corporate governance of many countries in the advanced, emerging and developing economies support this view by requiring that boards be composed in such a way as to have more non-executive directors.

There has been a wave of growing public scrutiny over board composition (Milkman, Akinola, \& Chang, 2018). In the view of IFC Women on Boards and in Business LeadershipIFC (2018), a board of directors requires diversity of skills, cultures, and views to really function effectively. Appointment of women on board of directors of corporate entities introduces the needed gender diversity and it is considered very important for achieving board effectiveness and enhanced sustainable strategic management (Velte, 2017).

The importance attached to such appointment derives from the benefits associated with it which include improved financial performance and shareholder value, enhanced customer and employee satisfaction, rising investor confidence, and greater market knowledge and reputation (IFC, 2018). Notwithstanding the benefits associated with women directorship, it is acknowledged that traditionally the number of women on corporate boards has been too low such that they are regarded as tokens (García-Izquierdo, Fernández-Méndez, \& Arrondo-García, 2018). The argument is that this low number of females on boards is observed in many countries across the world and that it is often below what is considered as a critical mass- the number that would give them a strong voice and enable them make significant contributions to the performance of the institutions (Kota, 2019).

Corporate governance issues have in recent years, been on front-burner among policy makers 
and other various stakeholders. Poor corporate governance has been blamed for some notable corporate failures and financial scandals in the recent past such as the collapse of Carillion the second largest construction giant in Britain in 2018, Tyco and Xerox in the United States of America (Adeoye 2013; Ailemen \& Oyero, 2013; Akingunola, Olusegun, \& Oluseyi, 2013; Gyamerah \& Agyie 2016; ACCA, 2018). Also the spate of collapsed airlines witnessed in Nigeria in the past decade is not unconnected with poor corporate governance in the aviation sector (Nweze, 2018).

Interest in corporate governance in banks particularly after the 2007-2009 global financial crisis has been heightened globally. The financial crisis and the resulting bank failures and previous bank failures and scandals have been blamed by many on poor corporate governance bordering on ineffective board composition, lack of transparency, poor organizational structure unethical issues among others (Martin \& Herrero, 2018; Hallerberg \& Markgraf, 2018; Gyamerah \& Agyie, 2016; Ailemen \& Oyero, 2013; Akingunola, Olusegun, \& Oluseyi, 2013; Sun, Stewart, \& Pollard, 2012).

The Sub Saharan Africa with a checkered banking history has had its own share of banking crisis traceable to poor corporate governance. The crisis assumed heightened dimension during the phase of government intervention/state-owned banks and the period between 1980s and 1990s specifically noted for banking crises (Mlachila, Park, \& Yabara, 2013; Daumont, Le Gall, \& Leroux, 2004).

\subsection{Statement of the Problem}

The key argument driving the strong advocacy for gender diversity on board of corporate bodies is that gender diversity on the board improves business performance of such bodies. A number of empirical studies on this much debated issue have been documented. However, the problem is that the findings are conflicting and without emphasis on the critical mass number. For instance, while García-Izquierdo, Fernández-Méndez and Arrondo-García (2018), Belhaj and Mateus (2016), Ramano et al. (2012), Jackson (2009) sited in WOBCP-Ghana (2018) are some of the studies indicating positive-gender diversity performance nexus; Pletzer, Nikolova, Kedzior and Voelpel, S. C. (2015), Ramly, Sok-Gee, Mustapha and Sapiei (2015), Post and Byron (2014) reported negative/negligible effect. This study is therefore, an attempt to resolve the conflict in the findings with special focus on the critical mass number using Sub Saharan banking sector data.

Another problem this study is poised to solve is the issue of global conflicting findings on the effect of a board composition with more non-executive/independent directors on performance of a firm. The national code of corporate governance of many countries across the globe requires that board of directors shall be composed in such a way that non-executive/independent directors shall be more in number. For instance in Nigeria national Code of corporate governance 2018 - NCNC2018 requires appropriate mix of executive, non-executive and independent non-executive directors such that majority of the board are non-executive directors (FRC, 2019). Non-executive / independent non-executive directors bring to bear their wide experience, knowledge, expertise and independent judgment on corporate entity's business and affairs. They are also expected to represent a strong 
independent voice on the board and by so doing ensure that strategic decisions and affairs of the entity are not influenced by personal interests of the executive directors. However, there have been conflicting global findings on the effect of non-executive/independent directors on performance of a deposit money bank. While Nwaubani (2019), Atuahene (2016), Dauda and Hawa (2016) among others documented a positive relationship between performance and non-executive directors; Yilmaz and Buyuklu (2016), John (2015) et cetera reported negative outcomes. Even Abu, Okpeh and Okpe (2016) documented no impact. To attempt to resolve the documented conflicts exploiting evidence from banking sector of Sub Saharan Africa constitutes another motivation for this study.

\subsection{Objectives of the Study}

The main objective of this study is to examine the effect of corporate governance on performance of deposit money banks in Sub Saharan Africa (SSA). Specific objectives are to determine the effect of:

1) board of directors with more non-executive directors on return on assets of deposit money banks in SSA

2) number of women directors/gender diversity on return on assets of deposit money banks in SSA

3) board of directors with more non-executive directors on net interest margin of deposit banks in SSA

4) number of women directors/gender diversity on net interest margin of deposit money banks in SSA

In line with the objectives four hypotheses were formulated in a null form and tested at $95 \%$ confidence level as stated below:

Ho1: Board of directors with more non-executive directors has no significant effect on return on assets of deposit money banks in SSA

Ho2: The effect of number of women directors/gender diversity on return on assets of deposit money banks in SSA is not significant

Ho3: Board of directors with more non-executive directors has no significant effect on net interest margin of deposit money banks in SSA

Ho4: Number of women directors/gender diversity has no significant effect on net interest margin of deposit money banks in SSA

\section{Corporate Governance as a Concept}

Corporate governance according to International Finance Corporation (IFC, 2016) is defined as the structures and processes by which companies are directed and controlled. Going further, the Corporation notes that good corporate governance leads to efficient performance of companies, improved access to capital and serves as risk mitigant and a check on mismanagement resulting in more accountability and transparency to all stakeholders. The author adds that African countries have joined the global drive for greater transparency and 
accountability. Perhaps this informs the position of World Bank that good corporate governance enhances firms' performance and access to capital (World Bank, 2005). A broader view of corporate governance is expressed in King IV Report on Corporate Governance for South Africa in which Corporate governance is also viewed as the exercise of ethical and effective leadership by the executive management of a corporate entity with the broad objective of achieving ethical culture, good performance, effective internal control and legitimacy (IoDSA, 2016).

Corporate governance can also be viewed from a more wider perspective as the processes and structures by which organizations are directed and controlled so that they will operate in a responsible, fair and transparent manner to all stakeholders while being held accountable in order to serve and sustain the interests and expectations of all stakeholders including their host communities and environment.

There are two broad frameworks to corporate governance codes namely: Rules-based and Principles-based. In rules- based framework, the firms are mandatorily required to comply with relevant principles and rules specified by the code with little or no exception to the rules. The philosophy behind this approach is the view that the companies need force of the law to observe principles and rules considered to be of best practices in either a particular sector or the economy as a whole. This framework does not give room for the entities/directors to bring their judgments' to bear in the application of the rules hence this approach lacks flexibility. However, under principles-based approach, the code specifies minimum principles and recommend best practices to enable the entities apply the principles. The entities are required to apply the principles based on their judgment in each circumstance but with the obligation to explain and justify why the principle is so applied. In essence, the directors are to adopt the "apply and explain approach" (Kaplan, 2012; Banff, 2016; FRC, 2018). The principles-based framework is characterized by flexibility and in the recent years, many countries are switching over to principles-based national code of corporate governance.

Currently corporate governance is increasingly assuming wider scope as the business environment is becoming increasingly more complex and dynamic. According to O'Kelley III, Goodman and Martin (2017) there are seven key global trends that should be of concerned to board of directors of firms. The trends relate to:

i) Better Investor Stewardship,

ii) Board Quality and Composition

iii) Compensation.

iv) Competing demand and activist investing

v) Environmental, Social, and Governance Risk

vi) Cybersecurity

vii) Human Capital

Ordinarily, the structures and processes by which companies are directed and controlled are primarily internal to a firm. However, as part of the government responsibility to provide 
legislation and regulations to ensure that the business entities adopt best practices and operate in a manner that protect the interests of all stake holders, codes of corporate governance have been introduced for adoption by organizations. This cuts across the globe. The necessity of adoption of the corporate governance codes for banks in Sub Saharan Africa stems particularly from the gross mismanagement hitherto witnessed in the region's banking sector particularly between the 1980s and 1990s. The mismanagement was fueled by technical and managerial incompetency and unethical practices which are some of the key issues being addressed by the corporate governance codes. This views agrees with the stand of Akingunola, Olusegun and Oluseyi (2013) who linked the bank distress in Nigeria in the 1990s to failure of professional ethics which manifested in such acts as creative accounting practices, disregard to internal control systems inter alia.

\section{Tokenism and Critical Mass Question}

It has been held that women directors make three unique contributions in corporate management which men may not likely make (Konrad \& Kramer, 2006). According to the authors, the women directors widen boards' discussions to cover the concerns of a wide range of stakeholders, including the community at large. They can also be more dogged in pursuing answers to challenging questions and through their seeming inherent collaborative approach to leadership, they improve communication and cohesion among directors and between the board and management. According to the authors, the number of women directors on boards however, affect these contributions and so raises the question of what the right number of female directors of corporate bodies should be.

Most corporate boards can boast of one female director or two but such director(s) are often regarded as tokens as they were just appointed to meet the minimum requirement of the law and to avoid public scrutiny (Kota, 2019; Milkman, Akinola, \& Chang, 2018; Torchia, Calabro, \& Huse, 2011). When there is only one woman director on the board, the female director finds it difficult to make her voice heard and she feels isolated and marginalized (Kota, 2019; Konrad \& Kramer, 2006). This is because most boards have average size of between 9 and 13 members with some having up to 20 (Soledad, Vinsrygg, Summeerfield, \& Reingold, 2018). Loop and DeNicola (2019) share the view expressed by Soledad et al. (2018) as they point out that one female director on a board with over nine directors is so insignificant that she cannot make any impact on performance of the board. Therefore, a solo woman director in this case is likely to have challenges getting her voice to be heard.

Also according to Kota (2019), as a token she is often perceived negatively, sometimes with a scorn, and the male directors may find it difficult to trust her. Consequently her ability to contribute meaningfully to the firms' performance is impaired. Furthermore, because of her high visibility, she is under extra performance pressures and often singled out. In view of these limitations associated with tokenism, it has been strongly suggested that tokenism must be abandoned for female directors to make a difference (Soledad et al., 2018). In the view of Konrad and Kramer (2006) adding a second woman to a board helps reduce the stereotypes which the solo female director suffers. However, the two women may be perceived as an untrusted separate group capable of conspiring against the board. Again they may not be distinguished from each other in terms of individual contributions. At this point, it becomes 
necessary to consider the question of the right number of women directors that must be introduced on the board to ensure the build-up of critical mass which would enable the unique and general contributions of women directors to result in enhanced company performance (Tochia, 2010).

With respect to this question, Soledad et al. (2018) and Konrad and Kramer (2006) are of the opinion that there is a complete change of attitude from the men towards the women directors when three or more women directors are introduced onto a board. At that critical mass, the female directors tend to be seen by their men counterparts as fellow directors without discrimination. The atmosphere becomes more collaborative and less combative-creating the enabling environment for the unique and general contributions of the women to meaningfully improve a firm's performance. Also, the board's overall performance is enhanced. Therefore three or more women directors on board have come to be regarded as the critical mass needed to cause the required paradigm shift in group dynamism with respect to board gender diversity. The number three and above have become a bench mark for qualifying a board as gender-diverse boards (Banaha \& Hasson 2018).

According to Soledad et al. (2018) by December 2018, large companies in 13 countries had on average at least three women directors per board with even five countries of Belgium, France, Germany Italy and Sweden recording at least four female directors. It may be noted that all these countries with the exception of Sweden operate under some form of quota system. The countries are those in Western Europe with average number of 3.8, followed by countries in Australia and New Zealand with 2.7, USA and Canada with 2.5, Middle East and Africa with 1.7, Eastern Europe with 1.2 and finally other Americas with 0.9. In terms of large company boards which appoint at least one female director, Soledad et al noted that across 44 countries, about $85 \%$ of such companies (representing 19 of the countries) did so in 2018. However, the authors also added that the overall percentage has not improved in the past two years. Regrettably, the remaining 15\% which represents such companies without a single woman director on their boards cut across 25 countries with China, Brazil and Russia in the lead.

Narrowing down to Africa/Sub Saharan Africa, it is observed that majority of African companies have at least one female director on their boards while one-third only have just one female director (Navitidad, 2015). However another one-third have zero women on their boards. According to the authors, the overall picture is that the majority of African companies could be said to have minimal women's presence on boards. This implies that the female directors in majority of African corporate organizations could be considered as tokens being minimal and less than the critical mass number three. Also the percentage of women directors on boards of blue chip companies (which account for 30\% of companies examined) is $14.4 \%$. Though, the $14.4 \%$ African performance lags behind the percentage of female directors in blue-chips in EU (18\%) and the US Fortune 500 (16.9\%), Africa is obviously leading other emerging regions when compared with Asia-Pacific 9.8\%, Latin America 5.6\%, and Middle East 1\%. The observations of Navitidad ( 2015) are based on her involvement in the first-ever study of female board membership in Africa, commissioned by African Development Bank, which examined 2013 data of 307 listed companies in 12 African countries (AfDB, 2015). 


\section{Corporate Governance in Sub Saharan Africa}

Corporate governance in SSA has been on the fore burner through the activities of African Corporate Governance Network (ACGN) and African Corporate Governance Programme (AFCGP) supported by International Finance Corporation (IFC, 2016). As reported by Klynveld Peat Marwick Goerdeler- KPMG (2017) a number of countries in SSA have adopted corporate governance code of practice or its equivalent, with most countries adopting their first codes from 2000 onwards. The report reveals that corporate governance requirements for listed companies in 15 countries across Africa meet Principles of Corporate Governance released in 2015 by Organization for Economic Co-operation and Development (OECD). The principles include: leadership and culture, strategy and performance, compliance and oversight, and stakeholder engagement

As documented in the report, South Africa ranks first in Africa while Kenya, Mauritius, Nigeria and Uganda are in the top five. The African Corporate Governance Network (ACGN) is a collaborative network of directors of organizations which is engaged in promoting effective and inclusive corporate governance in Africa (ACGN, 2016). According to the ACGN (2016) by 2015 the ACGN had a membership strength of about 16 countries of Africa and 7 affiliate members with most of the members coming from Sub Saharan Africa. The assessment of ACGN suggests that SSA countries are making progress in the area of adopting best corporate governance codes. For instance, some of the reviewed countries have issued new codes to further improve their corporate governance practices after the review exercise by ACGN in 2015. For instance, in 2016 Nigeria took time to harmonize and unify her codes for a number of major sectors in the economy (Proshare, 2016). However, the unified code was later suspended and eventually replaced by the new Nigerian Code of Corporate Governance 2018 (FRC, 2019). The new code which is principles-based has effective implementation date of January 01, 2020 (Kolawole, 2018). Also in 2016 South Africa replaced King III Code with King IV ( Michin \& Kelly ,2018) while the Capital Market Authority in Kenya issued a new code in 2016 titled "Code of Corporate Governance for Issuers of Securities to the Public 2016 " (Mulenwa, 2016, p. 1). Mauritius did the same through the National Committee on Corporate Governance (Financial Services Commission Circular Letter- FSC, 2018). The new code is captioned "National Code of Corporate Governance 2016." In the same 2016, Botswana developed its own new corporate governance code which is considered almost an adoption of South African King III Code (Michin \& Kelly, 2018; Josiah, Themba, \& Matenge, 2016) while Bank of Ghana in 2018 issued the final Corporate Governance Directive 2018 for compliance by banks, savings and loans companies, financial houses and financial holding companies (Bank of Ghana, 2018).

\section{The Theoretical Connections}

Board composition is very crucial to the success and survival of a firm particularly a deposit money bank because it is the board members who collectively formulate and implement policies of the bank on behalf of the owners of the business - shareholders. As First Bank Nigeria- FBN (2015, p. 105) acknowledges "good governance practices are best initiated and observed in the boardroom". An ineffective policy will ordinarily produce at best a less desirable result and an effective policy poorly implemented will not give the desired 
outcome.

The real issues surrounding board composition is the problem of conflicting interests among the directors and managers as agents of the shareholders on one hand against the interests of the shareholders- their principal on the other hand. This conflict is known as the agency problem which necessitates agency costs to the organization. The agency problem tends to hinder objective decisions which are in the best interests of the shareholders and other stakeholders for reasons which weigh more on personal interests of the agents.

The agency problem cuts across different organizations (Panda \& Leepsa, 2017). In the recent decades, the concept of agency problem has assumed an inclusive dimension with the problems grouped into three:- conflict of interest between the principal and agents, conflict of interest between the major and minor shareholders and conflict of interest between the owners of the organization (principal) and their creditors. According to Panda and Leepsa (2017) the agency problem associated with owners-creditors relationship crops up when the owners favors risky investment decisions which the creditors consider as acceptable. The agency problems are encapsulated in the agency theory which in turn is rooted in the firm theory.

The agency theory credited to Stephen Ross and Barry M. Mitnick (Mitnick, 2006) is concerned with the nature of principal-agent relationship, the rights and responsibilities of each party, the agency problems and how to minimize them via various corporate governance practices and observations aimed at controlling decisions and actions of the agent's in the modern firm. The theory can be considered as one of the oldest theories in the literature of the management and economics (Wasserman, 2006) and is also seen one of the most important theories in the finance and economics.

On the other hand the firm theory could be viewed as consisting a number of economic theories that explain and predict the nature of the firm, its existence, behavior, structure, and relationship with all stakeholders and the market (Kantarelis, 2007). The neo-classical or traditional firm is a single business entity whose entire operations are carried out by an entrepreneur with the main objective of profit maximization (Jhingan \& Stephen, 2009). It considers the sole objective of a firm to be profit maximization and measures profit as the difference between a firm's total revenue and total cost and asserts that in order to maximize profit, the firm is expected to maximize its revenues and minimize or stabilize its costs. However, the authors recognize that modern firms have varied objectives because of the complexities, politics and separation of ownership from management which characterize the firms. They note that modern firms are run by managers/directors while shareholders are the owners with separate roles and motives from those of the managers. These facts render the sole objective of profit maximization of the traditional firm unrealistic as the modern firm has varied objectives.

In 1964 Robin Marris developed a dynamic balanced growth maximizing managerial model of the firm in recognition of the varied interests of the managers and shareholders (Marris, 1964). Marris suggests that managers/directors are usually more concerned with salary, prestige, status, power, job security while shareholders are more interested in profits, market 
share and output (Rekhi, n. d.). This tendency introduces conflict of interests which implies that the directors/mangers may not act in the interest of the shareholders. This conflict of interests is known as the agency problem and was as far back as 1776 noted by Adam Smith (Panda \& Leepsa, 2017).

Apart from the two theories examined above, another relevant theory to this work is the Group Dynamics Theory. The Group Dynamics Theory revolves around a system of behaviors and psychological processes occurring within a social group- intragroup dynamics, or between social groups- intergroup dynamics (Backstrom, Huttenlocher, Kleinberg, \& Lan, 2006). The theory has its roots in psychology and sociology (Perryer, 2018; Hogg \& Williams, 2000) as experimental psychology is credited to psychologist Wilhelm Wundt, who originated the idea of group dynamics in 1912. Wundt was particularly interested in the psychology of communities. His theory influenced a sociologist Émile Durkheim who built upon it and is considered as the first to recognize the concept of public knowledge. Psychologist William McDougall on his part, propagated the concept of 'group mind' being a product the interaction of individuals and distinct from the minds of the individuals.

The term 'group dynamics' was eventually coined by social psychologist Kurt Lewin in 1947 to describe the positive and negative forces between groups of people (Dion, 2000). However, it was Bruce Tuckman that first in 1965 gave business application to the group dynamics (Perryer, 2018). He prescribed four stages through which group members should go through in order to for the members and group to function well. The stages are:

1. Forming - getting along with others (or pretending to)

2. Storming - being sincere and blunt in tackling issues and finding solutions to challenges even if that means tempers running high

3. Norming - understanding and getting use to each other and establishing trust, which leads to productivity

4. Performing - working efficiently and cooperatively to achieve a common goal.

The Tuchman model implies that stereotyping or isolating a member or subset of the group could breed distrust in the group. The sense of isolation or no acceptance in turn affects his/her contribution to achieving the group goals. This situation applies to a woman director considered as token and stereotyped as she is a lone voice among the male directors. Increasing the number of the female directors boosts their confidence and makes their voices to be heard.

It is therefore very imperative for not only organizations but governments to take well-thought out steps to checkmate this necessary evil called agent problem. The corporate governance code in most countries specifies that more number of non-executive directors shall be appointed on the board of directors of a firm as a way of minimizing the agent problem. Generally, corporate governance code and specific regulatory directives on board composition are part of the attempt at minimizing the problem of conflict of interests in organizations.

The relevance of the three theories (Agency Theory, Marris Managerial Theory of the Firm and the Group Dynamic Theory) discussed in this book lies in the fact that they all focus on 
people, conflicting interests of broad stakeholders, and the complex interactions between them on one hand and the complex structures which characterized the modern firm on the other hand.

\section{Empirical Review}

The review is carried out along the selected independent variables of the study: number of women on boards/gender diversity, board composition with more non-executive directors. On Gender diversity, the following empirical studies with positive outcomes were reviewed:García-Izquierdo, Fernández-Méndez and Arrondo-García (2018) examined the relationship between involvement of female directors both at board meetings and at audit and remuneration committees and Chief Executive Officer's Remuneration using a large sample of Spanish firms listed between 2011 and 2015. Results revealed inter-alia that involvement of female directors is associated with lower levels of CEO pay and CEO pay growth. Belhaj and Mateus (2016) investigated the impact of corporate governance (gender diversity, board size and the CEO duality) on European bank performance during the period 2002-2011using a sample of 73 banks from 11 European countries. Findings showed that the board gender diversity and board size have a positive and significant impact on bank performance.

Jeong and Harrison (2016) examined how female representation in top management teams and chief executive officer positions might affect firm performance. The authors employed meta-analytic techniques on a sample of 146 primary studies conducted in 33 different countries. Findings revealed that overall female representation in the upper echelons is positively and weakly related to long-term financial performance, but negatively and weakly related to short-term stock market returns. The result further showed that reduced strategic risk-taking is responsible for the improved financial performance. Equally the findings indicated that financial performance improvements are enhanced in environmental and organizational contexts that allow greater decision latitude to executives.

Hunt, Layton and Prince (2015) examined the relationship between the level of diversity and financial performance of 366 public companies across a range of industries in the United Kingdom, Canada, the United States, and Latin America employing the normalized Herfindahl-irschman index for diversity. The authors defined diversity as a greater share of women and a more mixed ethnic/racial composition in the leadership of large companies. The findings indicated inter-alia that gender diversity led to better financial performance particularly in United Kingdom.

Ramano et al. (2012) investigated the impact of corporate governance on performance of Italian banking group. Findings revealed that the presence of women on boards of directors has a positive impact on the bank performance measured by ROE and ROA. The authors attribute the finding to the contribution which women directors make to pool of skills knowledge, competencies and relationships useful to enhance the performances of the banks. However, the authors documented limited impact of the women directors on performance of the banks' holding companies. Terjesen, Sealy and Singh, V. (2009) reviewed over 400 publications on women directors covering various disciplines and came to the conclusion that gender diversity in corporate boards leads to positive performance outcomes. This work 
appears to be the first comprehensive meta analysis on women on corporate boards.

On the other hand, the following empirical studies reported negative gender diversity -performance nexus: Ramly, Sok-Gee, Zulkhairi and Sapiei (2015) examined the effect of gender diversity and board monitoring (board size and independence) on bank efficiency using abroad panel of ASEAN-5 listed commercial banks over the period 1999-2012. Finding indicated that gender diversity in bank board leads to cost and profit inefficiency. The authors concluded that appointment of female directors in bank board is merely to comply with regulatory requirement and that positive effect of an independent director towards monitoring and advisory roles of the board weakens if the director is a woman. Pletzer, Nikolova, Kedzior and Voelpel (2015 followed the meta-analysis adopted by Post and Bryon (2014) but with a more rigorous and controlled methodological approach to investigate the relationship between percentage of females on corporate boards and firm financial performance, proxied by return on assets, return on equity and Tobin's Q. The study used a sample of 52 articles published in peer-reviewed academic journals which met inclusion criteria out of 377 sources identified. The findings were compared to those in Post and Bryon (2014) which follows below. Results: female representation on corporate boards can positively or negatively relate to firm financial performance with likely small correlation coefficient.

Post and Byron (2014) reviewed 140 empirical studies on the relationship between women on boards and firm financial performance with combined sample of 90, 070. Post and Bryon (2014) statistically combined results from 140 empirical studies with a combined sample of 90,070 and examined whether these results depended on firms' legal/regulatory and socio-cultural contexts using meta-analysis technique. Findings: i) female board representation is positively related to accounting returns and market performance and that this relationship is more positive in countries with stronger shareholder protections, ii) it is also positively related to boards' monitoring and strategy involvement. However, the correlation is considered negligible at $\mathrm{r}=0.047$ and 0.014 for accounting and market returns.

Reviewed empirical works focusing on board composition are: Nwaubani (2019) examined the effect of Corporate governance on performance of deposit money banks in Sub Saharan Africa( SSA) with focus on appointment of directors. A sample of twelve banks from six SSA countries was used while panel data regression analysis was employed to analyze the data. The author introduced and adopted a new approached he called the improvised randomized experiment. The study revealed among others that a board with more non-executive directors has positive but insignificant effect on ROA. It also indicated strong positive correlation with both ROA and NIM. A hypothetical board with more executive directors showed positive and significant effect on NIM while indicating negative and insignificant effect on ROA. Atuahene (2016) investigated the effect of corporate governance on financial performance of Ghanaian universal banking companies during the period 2006-2014 employing multiple regression panel data approach. The findings showed that board composition, board size, bank size and foreign ownership have positive insignificant relationship with profitability (return on asset and return on equity). Dauda and Hawa (2016) examined the impact of corporate governance on the performance of 10 Nigerian commercial banks for the period 2000-2009 using fixed effects model for a panel least square regression analysis. The results 
revealed a positive significant relationship between return on assets and board composition while indicating an inverse significant relationship between return on assets and board size as well as audit committee. The study recommended that the board size should be limited to a sizeable number and the audit committee be composed of mainly directors with adequate skills, and who are familiar with the banking terrain.

Nodeh, Anuar, Suresh and Raftnia (2016) evaluated the role of bank size as moderator on relationship between board independence and board size with banks financial performance using the data of 37 Malaysian banks. The results revealed that board independence and board size have positive impact on firm financial performance. Also the relationship between determinants of board structure (board size, and board independence) and financial performance is moderated by firm size. Yilmaz and Buyuklu (2016) evaluated the impact of corporate governance on firm performance in Turkey using a sample of 92 listed firms listed on the Istanbul Stock Exchange (BIST) for the period 2007-2013.Findings showed a negative insignificant relationship between board Independence and board size and ROA implying that, larger independent members and larger board size and negatively impact the profit of firms. Firm size is significant but negatively affects ROA. John (2015) examined the relationship between corporate governance and performance of the Nigerian banking sector for the period 2006-2014 employing Pearson's Correlation Technique. The study covered all the 21 commercial banks in Nigeria by 2014. Findings revealed that there is negative significant relationship between board composition, board size and performance on one hand and positive significant correlation between directors' equity and performance on the other hand.

\section{Research Methodology}

The research design adopted in this work is ex-post facto. Secondary data from 12 deposit money banks selected from 6 Sub Saharan African countries of Nigeria, South Africa, Ghana, Kenya, Mauritius and Botswana were collected for the period 2004-2006. The banks are: Guaranty TrustBank, First Bank, Zenith Bank and Access Bank for Nigeria; Standard Bank and Nedbank for South Africa: Kenya Commercial Bank and Equity Bank for Kenya; Mauritius Commercial Bank and SBM Bank for Mauritius; Standard Chartered Bank of Ghana for Ghana and Barclays Bank of Botswana for Botswana. The selection of the six countries was primarily based on sub regional representation. The sub regions are: West Africa represented by Nigeria and Ghana, Southern Africa by South Africa and Botswana, East Africa by Kenya and the Small Island Countries of SSA by Mauritius. Panel data multiple regression approach was employed to analyze the data with the aid of EViews 9 and SPSS (20). The dependent variables used in this study are bank-level factors and they are Return on Assets (ROA) to proxy profitability and Net Interest Margin (NIM) to measure efficiency. The independent variables are number of women directors (WDIRTS) and board of directors made up of more non-executive directors represented by a dummy (NEDIRTS). The final model is a modified version of the models adopted by Atuahene (2016) and Flamini, McDonald and Schumacher (2009) and it is given as:

$$
\text { ROAic, } \mathrm{t} / \text { NIMic }, \mathrm{t}=\alpha+\sum \beta 1 \text { WDIRTSic }, \mathrm{t}+\sum \beta 2 \text { NEDIRTS ic }, \mathrm{t}+\mathrm{Vi}, \mathrm{t}
$$

Where: 
ROAic, $t$ is the return on total assets of bank $\mathrm{i}$ in country $\mathrm{c}$ for period $\mathrm{t}$;

NIMic, $t$ is the net interest margin of bank $i$ in country $\mathrm{c}$ for period $\mathrm{t}$.

WDIRT ict is the number of women directors of bank $\mathrm{i}$ in country $\mathrm{c}$ for period $\mathrm{t}$,

NEDIRTS ic,t is board composition of bank $\mathrm{i}$ in country c for period $\mathrm{t}$,

$\alpha$ is the constant for the model

$\beta 1$ to $\beta 2$ are parameters/ beta coefficients to be estimated

$v i t=u$ it $+\varepsilon$ it is the composite disturbance factor, while $u$ it $=$ between-entity errors and $\varepsilon$ it $=$ within-entity errors (the idiosyncratic errors).

Table 3.1 Measurement of Variables of the Study

\begin{tabular}{|c|c|l|c|}
\hline S/n & $\begin{array}{c}\text { Variable } \\
\text { Dependent } \\
\text { /Independent }\end{array}$ & Measurement & $\begin{array}{c}\text { A priori } \\
\text { Expectation }\end{array}$ \\
\hline 1 & $\begin{array}{c}\text { ROA - Return } \\
\text { on Assets } \\
\text { (Dependent })\end{array}$ & $\begin{array}{l}\text { Profit before tax divided by total tangible asset } \\
\text { Iacobelli, (2017), Mungly et al., (2016) or as given in } \\
\text { the annual accounts of each bank }\end{array}$ & \\
\hline 2 & $\begin{array}{c}\text { NIM - Net } \\
\text { Interest Margin } \\
\text { (Dependent) }\end{array}$ & $\begin{array}{c}\text { Net interest income expressed as a percentage of net } \\
\text { earning assets (Kosmidou, Tanna \& Pasiouras, 2012), } \\
\text { or as given in the annual accounts of each bank. }\end{array}$ & \\
\hline 3 & $\begin{array}{c}\text { WDIRTS- } \\
\text { Number of } \\
\text { Women } \\
\text { Directors } \\
\text { (Independent) }\end{array}$ & $\begin{array}{l}\text { Belhaj and Mateus (2016)-\% of women directors } \\
\text { Ramly, Sok-Gee, Zulkhairi and Sapiei (2015) }\end{array}$ & + \\
\hline 4 & $\begin{array}{c}\text { NEDIRTS- non } \\
\text { executive } \\
\text { directors } \\
\text { dummy } \\
\text { (Independent) }\end{array}$ & $\begin{array}{l}\text { Nwaubani (2019), Atuahene (2016), Dauda and Hawa } \\
\text { (2016), Yilmaz and Buyuklu (2016) }\end{array}$ & \\
\hline
\end{tabular}

Source: Authors' Compilation, 2019

\subsection{Diagnostic Tests - Panel Stationarity Tests}

The variables were subjected to panel data unit root tests in order to check the problem of spurious regression. Consequently the data were subjected to five stationarity tests as availed by EViews 9. The tests are Levin, Lin and Chut t; Breitung t-stat; Im, Pesaran and Shin W-stat; ADF-Fisher Chi-square and PP-Fisher Chi-square. The summarized results in Tables1- 4 confirm that all the variables except return on asset (ROA) are stationary at level under the five tests respectively. The ROA is stationary at first difference [I(1)]. The data set of this study appears insufficient for use of autoregressive distributed-lagged (ARDL) model. 
However, model selection for the ROA was subjected to Hausman test.

\subsection{Multicolinearity Check}

The size of the correlation coefficient of each of the independent variables in Table 7 below suggests that the model does not suffer from serious multicollinearity.

\subsection{Data Analysis Technique}

Panel data multiple regression approach is employed to analyze the balanced panel data under random effects and fixed effects models. The use of fixed or random effects model for each variable is dictated by result of Hausman test. The random effects model is adopted when it appears that the error terms (unique errors) are not correlated with the explanatory variables (Torres-Reyna, 2007). However, whether to continue with the random effects or not depends on result of Hausman test. The null hypothesis in the Hausman test is that the preferred model is random effects model (as it is assumed that the unique errors are not correlated with the regressors), otherwise, fixed effects is the preferred model. The null hypothesis (random effects model) is rejected and the fixed effects model accepted if the resulting p-value from the test is less than the selected level of significance.

\section{Data Presentation and Analysis}

\subsection{Data Presentation}
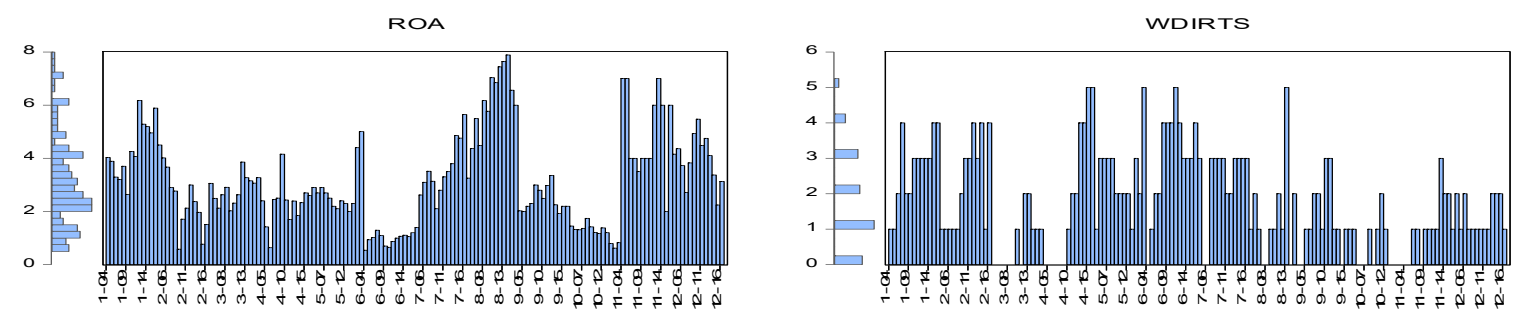

NEDIRTS
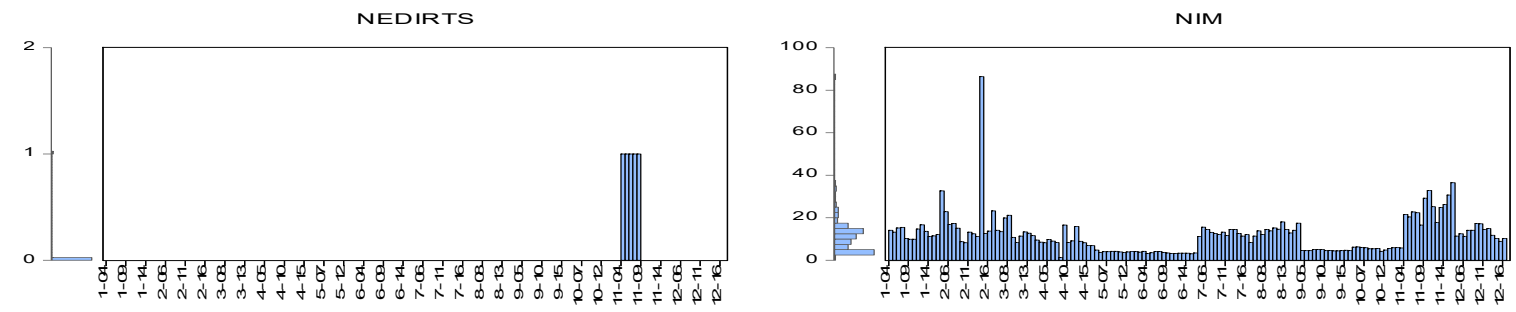

Figure 1. Movement of the Variables (without dummy) within the Period, 2004-2016. Source: E-Views 9 Output, 2019

The Figure 1 above indicates that the variables fluctuated during the period of the study reflecting changes in board composition, economic situations and market structures. Net interest margin-NIM shown above seems to have been influenced by extreme values recorded by First Bank Nigeria particularly and Standard Chartered Bank of Ghana. First Bank Nigeria recorded the highest NIM of $86.32 \%$ in 2014 suggestively following risk assets restructuring which may have resulted in lower loan value. This value is the highest within the period of the study (2004-2016). Standard Chartered Bank of Ghana also documented a NIM of $36.45 \%$ in 2016 . However, the extreme values of NIM were one-off. 
Table 2. Descriptive Statistics of the Variables of the Study

Date: 06/13/19 Time: 12:37

Sample: 20042016

\begin{tabular}{ccccc} 
& ROA & WDIRTS & NEDIRTS & NIM \\
Mean & 3.144103 & 1.717949 & 0.032051 & 11.61051 \\
Median & 2.800000 & 1.000000 & 0.000000 & 11.24500 \\
Maximum & 7.890000 & 5.000000 & 1.000000 & 86.32000 \\
Minimum & 0.540000 & 0.000000 & 0.000000 & 1.200000 \\
Std. Dev. & 1.712456 & 1.371577 & 0.176704 & 9.059324 \\
Skewness & 0.729817 & 0.517316 & 5.313484 & 4.013356 \\
Kurtosis & 2.967070 & 2.400791 & 29.23311 & 31.36628 \\
Jarque-Bera & 13.85551 & 9.291847 & 5207.206 & 5648.981 \\
Probability & 0.000980 & 0.009601 & 0.000000 & 0.000000 \\
Sum & 490.4800 & 268.0000 & 5.000000 & 1811.240 \\
Sum Sq. Dev. & 454.5386 & 291.5897 & 4.839744 & 12721.06 \\
Observations & 156 & 156 & 156 & 156 \\
\hline
\end{tabular}

Source EViews 9 Output, 2019

Note: ROA Return on Assets, NIM Net interest Income, WDIRT No. of Women Directors, NEDIRTS dummy for Non-Executive Directors.

From the Table 2 above, ROA has mean of $3.144 \%$, a median of $2.80 \%$ and minimum value of $0.54 \%$. These statistics suggest that the deposit money banks in Sub Saharan Africa were on average profitable within the period of this study. It may be noted that ROA gives a lower profitability rate because it employs total/gross assets at year ends as against return on average assets (ROAA). The $3.144 \%$ therefore, can be regarded as a conservative figure as it could have been higher under ROAA. Also the Table indicates that the average number of women directors within the period is about 2 which could be considered as a token as it is less than what is generally regarded as the critical mass threshold (Kota, 2019). The implications of tokenism and critical mass size are equally examined under discussion of findings.

\subsection{Results of the Panel Data Regression Analysis}

Table 3 below shows that number of women directors (WDIRT) has negative insignificant relationship with both ROA and NIM. Conversely, board with more non-executive directors (NDIRTS) correlates positively and significantly with ROA and NIM. The Table 3 also indicates that there is positive significant correlation between ROA and NIM.

Table 7. Panel Data Regression Result For the Hypotheses 1-4 
Table 3. Correlation Among the Variables

\begin{tabular}{cccccc}
\hline \multicolumn{5}{c}{ Correlations } \\
\hline \multirow{2}{*}{ ROA } & ROA & WDIRTS & NEDIRTS & NIM \\
& Pearson Correlation & 1 & -.010 & $.209^{* *}$ & $.393^{* *}$ \\
& Sig. (2-tailed) & & .902 & .009 & .000 \\
\multirow{2}{*}{ WDIRTS } & N & 156 & 156 & 156 & 156 \\
& Pearson Correlation & -.010 & 1 & $-.175^{*}$ & -.056 \\
& Sig. (2-tailed) & .902 & & .028 & .488 \\
\multirow{2}{*}{ NEDIRTS } & N & 156 & 156 & 156 & 156 \\
& Pearson Correlation & $.209^{* *}$ & $-.175^{*}$ & 1 & $.183^{*}$ \\
& Sig. (2-tailed) & .009 & .028 & & .022 \\
& N & 156 & 156 & 156 & 156 \\
NIM & Pearson Correlation & $.393^{* *}$ & -.056 & $.183^{*}$ & 1 \\
& Sig. (2-tailed) & .000 & .488 & .022 & \\
& N & 156 & 156 & 156 & 156 \\
\hline
\end{tabular}

**. Correlation is significant at the 0.01 level (2-tailed).

*. Correlation is significant at the 0.05 level (2-tailed).

Source: SPSS (20) Output 2019. Note: ROA Return on Assets, NIM Net interest Income, WDIRTS No. of Women Directors, NEDIRTS Non-Executive Directors Dummy

The results of the panel regression analysis are shown on subTables $4.3 \mathrm{~A}$ to $4.3 \mathrm{~F}$ and are discussed under Findings below.

Table 4.3A Fixed Effects Result With Respect To ROA: Ho1-Ho2

Dependent Variable: ROA

Method: Panel Least Squares

Date: 06/13/19 Time: 13:50

Sample: 20042016

Periods included: 13

Cross-sections included: 12

Total panel (balanced) observations: 156

\begin{tabular}{ccccc} 
Variable & Coefficient & Std. Error & t-Statistic & Prob. \\
\hline C & 3.146338 & 0.237966 & 13.22182 & 0.0000 \\
WDIRTS & -0.044181 & 0.110559 & -0.399614 & 0.6900 \\
NEDIRTS & 2.298368 & 0.805297 & 2.854062 & 0.0050 \\
& \multicolumn{2}{c}{ Effects Specification }
\end{tabular}

Period fixed (dummy variables) 


$\begin{array}{cccc}\text { R-squared } & 0.088599 & \text { Mean dependent var } & 3.144103 \\ \text { Adjusted R-squared } & -0.001895 & \text { S.D. dependent var } & 1.712456 \\ \text { S.E. of regression } & 1.714078 & \text { Akaike info criterion } & 4.006839 \\ \text { Sum squared resid } & 414.2669 & \text { Schwarz criterion } & 4.300095 \\ \text { Log likelihood } & -297.5335 & \text { Hannan-Quinn criter. } & 4.125947 \\ \text { F-statistic } & 0.979064 & \text { Durbin-Watson stat } & 0.281568 \\ \text { Prob(F-statistic) } & 0.477762 & & \end{array}$

Source EViews 9 Output, 2019

Table 4.3B Random Effects Result With Respect To ROA

Dependent Variable: ROA

Method: Panel EGLS (Period random effects)

Date: 06/13/19 Time: 14:04

Sample: 20042016

Periods included: 13

Cross-sections included: 12

Total panel (balanced) observations: 156

Swamy and Arora estimator of component variances

\begin{tabular}{ccccc}
\hline Variable & Coefficient & Std. Error & t-Statistic & Prob. \\
\hline C & 3.018900 & 0.227416 & 13.27481 & 0.0000 \\
WDIRTS & 0.034308 & 0.101960 & 0.336488 & 0.7370 \\
NEDIRTS & 2.067376 & 0.791418 & 2.612242 & 0.0099 \\
& Effects Specification & & Rho \\
Period random & & S.D. & 0.0000 \\
Idiosyncratic random & Weighted Statistics & 1.714078 & 1.0000 \\
R-squared & & Mean dependent var & 3.144103 \\
Adjusted R-squared & 0.044207 & S.D. dependent var & 1.712456 \\
S.E. of regression & 1.685084 & Sum squared resid & 434.4449 \\
F-statistic & 3.538235 & Durbin-Watson stat & 0.309931 \\
Prob(F-statistic) & 0.031466 & & \\
& Unweighted Statistics & \\
R-squared & 0.044207 & Mean dependent var & 3.144103 \\
Sum squared resid & 434.4449 & Durbin-Watson stat & 0.309931 \\
\hline
\end{tabular}

Source EViews9 Output, 2019 
Table 4.3C Hausman Test With Respect To ROA

\begin{tabular}{|c|c|c|c|c|}
\hline \multicolumn{5}{|c|}{ Correlated Random Effects - Hausman Test } \\
\hline \multicolumn{5}{|c|}{ Equation: Untitled } \\
\hline \multicolumn{5}{|c|}{ Test period random effects } \\
\hline Test Sumr & & Chi-Sq. Statistic & Chi-Sq. d.f. & Prob. \\
\hline Period ran & & 3.477057 & 2 & 0.1758 \\
\hline \multicolumn{5}{|c|}{ Period random effects test comparisons: } \\
\hline Variable & Fixed & Random & Var(Diff.) & Prob. \\
\hline WDIRTS & -0.044181 & 0.034308 & 0.001827 & 0.0663 \\
\hline NEDIRTS & 2.298368 & 2.067376 & 0.022160 & 0.1207 \\
\hline \multicolumn{5}{|c|}{ Period random effects test equation: } \\
\hline \multicolumn{5}{|c|}{ Dependent Variable: ROA } \\
\hline \multicolumn{5}{|c|}{ Method: Panel Least Squares } \\
\hline \multicolumn{5}{|c|}{ Date: 06/21/19 Time: 21:49 } \\
\hline \multicolumn{5}{|c|}{ Sample: 20042016} \\
\hline \multicolumn{5}{|c|}{ Periods included: 13} \\
\hline \multicolumn{5}{|c|}{ Cross-sections included: 12} \\
\hline \multicolumn{5}{|c|}{ Total panel (balanced) observations: 156} \\
\hline Variable & Coefficient & Std. Error & t-Statistic & Prob. \\
\hline $\mathrm{C}$ & 3.146338 & 0.237966 & 13.22182 & 0.0000 \\
\hline WDIRTS & -0.044181 & 0.110559 & -0.399614 & 0.6900 \\
\hline NEDIRTS & 2.298368 & 0.805297 & 2.854062 & 0.0050 \\
\hline \multicolumn{5}{|c|}{ Effects Specification } \\
\hline \multicolumn{5}{|c|}{ Period fixed (dummy variables) } \\
\hline R-squared & 0.088599 & \multicolumn{2}{|c|}{ Mean dependent var } & 3.144103 \\
\hline Adjusted R-squared & -0.001895 & \multicolumn{2}{|c|}{ S.D. dependent var } & 1.712456 \\
\hline S.E. of regression & 1.714078 & \multicolumn{2}{|c|}{ Akaike info criterion } & 4.006839 \\
\hline Sum squared resid & 414.2669 & \multicolumn{2}{|c|}{ Schwarz criterion } & 4.300095 \\
\hline Log likelihood & -297.5335 & \multicolumn{2}{|c|}{ Hannan-Quinn criter. } & 4.125947 \\
\hline F-statistic & 0.979064 & \multicolumn{2}{|c|}{ Durbin-Watson stat } & 0.281568 \\
\hline Prob(F-statistic) & 0.477762 & & & \\
\hline
\end{tabular}

Table 4.3D Fixed Effects Result With Respect To NIM: Ho3-Ho4 
Date: 06/13/19 Time: 14:10

Sample: 20042016

Periods included: 13

Cross-sections included: 12

Total panel (balanced) observations: 156

\begin{tabular}{ccccc} 
Variable & Coefficient & Std. Error & t-Statistic & Prob. \\
C & 11.78018 & 1.274541 & 9.242685 & 0.0000 \\
WDIRTS & -0.282447 & 0.592154 & -0.476983 & 0.6341 \\
NEDIRTS & 9.845541 & 4.313161 & 2.282674 & 0.0239 \\
\multicolumn{4}{c}{ Effects Specification } & \\
R-squared & Period fixed (dummy variables) & 11.61051 \\
Adjusted R-squared & -0.065808 & Mean dependent var & 9.059324 \\
S.E. of regression & 9.180581 & S.D. dependent var & 7.363270 \\
Sum squared resid & 11883.91 & Akaike info criterion & 7.656525 \\
Log likelihood & -559.3350 & Schwarz criterion & 7.482377 \\
F-statistic & 0.709471 & Dannan-Quinn criter. & 1.109397 \\
Prob(F-statistic) & 0.762127 & &
\end{tabular}

Table 4.3 E Random Effects Result With Respect To NIM

Dependent Variable: NIM

Method: Panel EGLS (Period random effects)

Date: 06/13/19 Time: 14:19

Sample: 20042016

Periods included: 13

Cross-sections included: 12

Total panel (balanced) observations: 156

Swamy and Arora estimator of component variances

$\begin{array}{ccccc}\text { Variable } & \text { Coefficient } & \text { Std. Error } & \text { t-Statistic } & \text { Prob. } \\ \text { C } & 11.59430 & 1.218036 & 9.518848 & 0.0000 \\ \text { WDIRTS } & -0.161839 & 0.546098 & -0.296356 & 0.7674 \\ \text { NEDIRTS } & 9.180436 & 4.238828 & 2.165796 & 0.0319\end{array}$

Effects Specification

S.D. Rho

Period random

$0.000000 \quad 0.0000$ 
Idiosyncratic random

9.180581

1.0000

Weighted Statistics

\begin{tabular}{cccc} 
R-squared & 0.034204 & Mean dependent var & 11.61051 \\
Adjusted R-squared & 0.021579 & S.D. dependent var & 9.059324 \\
S.E. of regression & 8.961044 & Sum squared resid & 12285.95 \\
F-statistic & 2.709295 & Durbin-Watson stat & 1.144982 \\
Prob(F-statistic) & 0.069779 & & \\
& Unweighted Statistics & \\
R-squared & 0.034204 & Mean dependent var & 11.61051 \\
Sum squared resid & 12285.95 & Durbin-Watson stat & 1.144982 \\
\hline
\end{tabular}

Table 4.3F Hausman Test Results With Respect To NIM

Correlated Random Effects - Hausman Test

Equation: Untitled

Test period random effects

Test Summary

Chi-Sq. Statistic

Chi-Sq. d.f.

Prob.

Period random

0.707975

2

0.7019

Period random effects test comparisons:

$\begin{array}{ccccc}\text { Variable } & \text { Fixed } & \text { Random } & \text { Var(Diff.) } & \text { Prob. } \\ \text { WDIRTS } & -0.282447 & -0.161839 & 0.052423 & 0.5984 \\ \text { NEDIRTS } & 9.845541 & 9.180436 & 0.635698 & 0.4042\end{array}$

Period random effects test equation:

Dependent Variable: NIM

Method: Panel Least Squares

Date: 06/13/19 Time: 14:21

Sample: 20042016

Periods included: 13

Cross-sections included: 12

Total panel (balanced) observations: 156

$\begin{array}{ccccc}\text { Variable } & \text { Coefficient } & \text { Std. Error } & \text { t-Statistic } & \text { Prob. } \\ \text { C } & 11.78018 & 1.274541 & 9.242685 & 0.0000 \\ \text { WDIRTS } & -0.282447 & 0.592154 & -0.476983 & 0.6341 \\ \text { NEDIRTS } & 9.845541 & 4.313161 & 2.282674 & 0.0239\end{array}$

Effects Specification

Period fixed (dummy variables) 


$\begin{array}{cccc}\text { R-squared } & 0.065808 & \text { Mean dependent var } & 11.61051 \\ \text { Adjusted R-squared } & -0.026948 & \text { S.D. dependent var } & 9.059324 \\ \text { S.E. of regression } & 9.180581 & \text { Akaike info criterion } & 7.363270 \\ \text { Sum squared resid } & 11883.91 & \text { Schwarz criterion } & 7.656525 \\ \text { Log likelihood } & -559.3350 & \text { Hannan-Quinn criter. } & 7.482377 \\ \text { F-statistic } & 0.709471 & \text { Durbin-Watson stat } & 1.109397 \\ \text { Prob(F-statistic) } & 0.762127 & & \end{array}$

8.4 Summary of Results of the Fixed Effects and Random Effects Models

Table 5. Summary of Random Effects and Fixed Effects Models' Results for ROA

$$
\text { Fixed Effects-FE Random Effects-RE }
$$

\begin{tabular}{|c|c|c|c|c|c|c|c|}
\hline $\begin{array}{c}\text { Independent } \\
\text { Variables }\end{array}$ & Details in: & $\begin{array}{l}\text { Beta } \\
\text { Coef. } \\
\text { under } \\
\text { FE }\end{array}$ & $\begin{array}{c}\text { P-valu } \\
\text { e } \\
\text { Under } \\
\text { FE }\end{array}$ & $\begin{array}{l}\text { Beta } \\
\text { Coef. } \\
\text { Under } \\
\text { RE }\end{array}$ & $\begin{array}{l}\text { P-valu } \\
\text { e } \\
\text { Under } \\
\text { RE }\end{array}$ & $\begin{array}{c}\text { Adopted } \\
\text { Model based } \\
\text { on Hausman } \\
\text { Test Result }\end{array}$ & $\begin{array}{c}\text { Details of } \\
\text { Hausman } \\
\text { Test in: }\end{array}$ \\
\hline WDIRT & $\begin{array}{c}\text { Table4.3A } \\
-B\end{array}$ & -0.0824 & 0.6341 & $\begin{array}{c}-0.161 \\
8\end{array}$ & 0.7674 & $\begin{array}{l}\text { Random } \\
\text { Effects }\end{array}$ & $\begin{array}{l}\text { Table } \\
4.3 \mathrm{C}\end{array}$ \\
\hline NEDIRT & -do- & 9.8455 & 0.0239 & 9.1804 & 0.0319 & $\begin{array}{l}\text { Random } \\
\text { Effects }\end{array}$ & -do- \\
\hline
\end{tabular}

Source: Extracted from Eview 9 Results (Tables 4.3A-4.3F), 2019

Table 6 Summary of Random Effects and Fixed Effects Models' Results For NIM:

$$
\text { Fixed Effects-FE Random Effects-RE }
$$

\begin{tabular}{|c|c|c|c|c|c|c|c|}
\hline $\begin{array}{c}\text { Independe } \\
\text { nt } \\
\text { Variables }\end{array}$ & Details in: & $\begin{array}{l}\text { Beta } \\
\text { Coef. } \\
\text { under } \\
\text { FE }\end{array}$ & $\begin{array}{c}\text { P-valu } \\
\text { e } \\
\text { Under } \\
\text { FE }\end{array}$ & $\begin{array}{l}\text { Beta } \\
\text { Coef. } \\
\text { Under } \\
\text { RE }\end{array}$ & $\begin{array}{c}\text { P-value } \\
\text { Under } \\
\text { RE }\end{array}$ & $\begin{array}{c}\text { Adopted } \\
\text { Model based } \\
\text { on Hausman } \\
\text { Test Result }\end{array}$ & $\begin{array}{c}\text { Details of } \\
\text { Hausman } \\
\text { test in: }\end{array}$ \\
\hline WDIRT & $\begin{array}{c}\text { Table4.3D- } \\
\text { E }\end{array}$ & -0.0441 & 0.6910 & 0.0343 & 0.7370 & $\begin{array}{l}\text { Random } \\
\text { Effects }\end{array}$ & Table $4.3 \mathrm{~F}$ \\
\hline NEDIRT & - do- & 2.2983 & 0.0050 & 2.0673 & 0.0099 & $\begin{array}{c}\text { Random } \\
\text { Effects }\end{array}$ & -do- \\
\hline
\end{tabular}

Source: Extracted from Eview9 Results, 20 


\section{Discussion of Findings}

From the Summary of Results in Tables 5 and 6 it could be seen that board composition with more non-executive directors(NEDIRTS) indicated very strong and significant positive effect on return on assets (ROA) and net interest margin (NIM) in particular (where it commands a beta/coefficient value of 9.1804). The positive effect of this nonexecutive - dominant board cuts across the Random Effects and Fixed Effects models.

These positive outcomes tend to point to the benefits of board monitoring role and provision of balancing influence by the nonexecutive directors. These activities help to moderate management expenses and expenditure thereby increasing the bottom lines of the banks. The very strong positive outcome associated with NIM could in part be explained from the financial intermediation process of the banks. Banks borrow from depositors and lend to credit customers to generate interest income. When the banks deduct their interest expenses from the interest income they have interest income. The monitoring activities of the nonexecutive directors appears to reduce incidence of policy loans often associated with loans to executive directors and thus enhances net interest income of the banks.

The positive effect outcomes indicated by board with more nonexecutive directors agree with the positive impact documented by Nwaubani (2019), Atuahene (2016), Dauda and Hawa (2016), Nodeh, Anuar, Suresh and Raftnia (2016, Hassan and Farouk (2014) but contradict the negative effect reported in Yilmaz and Buyuklu (2016), John (2015) and Olatunji and Ojeka (2011).

Though, generally there is still conflict in the findings on effect of nonexecutive directors, the positive outcome in this book has increased the number of works with positive impact. The positive result appears to be gaining grounds and thus moving towards resolving the conflict. The positive effect of NEDIRTS coupled with its positive correlation with both ROA and NIMs tends to justify the Corporate Governance Code preference for more nonexecutive directors on corporate boards.

The Tables 5and 6 also show that women directors/gender diversity (WDIRTS) has negative insignificant effect on both ROA and NIM under the preferred random effects model. The very small size of the associated coefficient/beta of the WDIRTS confirms that the effect is very insignificant and could be regarded as no effect. The mean size of women directors in the twelve selected banks on Table 4.1 is $2(1.71)$. This size qualifies the female directors as token and is consistent with the view of Navitidad (2015) that the majority of African companies could be said to have minimal women's presence on boards. This is appreciated when the number is considered against average and maximum board sizes of 13 and 22 members of the same twelve banks (Nwaubani \& Idika, 2019). The mean size of 2 equally confirms the overall global view that most corporate boards can boast of one female director or two but such director(s) are often regarded as tokens as they were just appointed to meet the minimum requirement of the law and to avoid public scrutiny (Kota, 2019; Milkman, Akinola, \& Chang, 2018; Torchia, Calabro, \& Huse ,2011). The negative effect shown by women directors in this work is consistent with the outcomes recorded in Pletzer, Nikolova, Kedzior and Voelpel, S.C. (2015), Ramly, Sok-Gee, Mustapha and Sapiei (2015), Post and 
Byron (2014) but contradicts the findings in García-Izquierdo, Fernández-Méndez and Arrondo-García (2018), Belhaj and Mateus ( 2016), Ramano et al. (2012), Jackson (2009) sited in WOBCP-Ghana (2018). This shows that the conflict over effect of women directors is yet to be settled.

In terms of correlation among the variables used in this work (Table 3), women directors/gender diversity correlates negatively and insignificantly with ROA and NIM. This outcome may have been influenced by the overall picture of gross under representation of the women on boards which is portrayed by the descriptive statistics on Table 2. In that Table, the mean number of women directors is 2 (1.71) with median and minimum numbers as 1 and zero respectively. The median number of 1 implies that though the average number is 2, many of the banks settled for just 1 woman director- that is tokenism at its worst level. The board of directors with more number of nonexecutive directors (NEDIRTS) shows positive significant relationship with both return on assets (ROA) net interest margin (NIM).

\section{Conclusion and Recommendations}

\subsection{Conclusion}

This study examined the effect of board composition on performance of banks in Sub Saharan Africa (SSA) with special focus on the critical mass question. Secondary data on six SSA countries and twelve banks from the six countries for the period 2004 to 2016 were used. The data were subjected to panel data Unit Root tests. Panel data multiple regression approach was employed to analyze the data. Fixed effects and Random effects models were adopted based on outcome of Hausman tests.

The findings revealed among others that board composition with more nonexecutive directors (NEDIRTS) has significant positive effect on return on assets (ROA) and net interest income (NIM) of the banks in SSA. It was also indicated that NEDIRTS equally correlates positively and significantly with ROA and NIM of the banks. Women directors/gender diversity has negative insignificant effect on both ROA and NIM. It is therefore, concluded that though, nonexecutive directors have strong positive significant effect on performance of deposit money banks in Sub Saharan Africa and women directors indicate very negligible effect, the conflicts over the effect of the two variables are not yet fully resolved.

\subsection{Recommendations}

- It is recommended that though board of directors of deposit money banks (DMBs) in Sub Saharan Africa (SSA) should consist more of non-executive directors, each bank must ensure that strong, dynamic and effective internal control systems which promote culture of integrity and professionalism in management are put in place.

- The DMBs should make room for at least three female directors in their boards in order to achieve a critical mass held to lead to meaningful contributions of the female directors. This is likely to improve the insignificant positive effect of the gender diversity revealed in this study.

- Operation and enforcement of gender quota may be adopted by nations to enhance appointment of women on boards. 
- Adoption of the principles-based framework of corporate governance is recommended for countries and DMBs in SSA as it gives room for substance over form.

\section{References}

Abu, S. O., Okpeh, A. J., \& Okpe, U. J. (2016). Board characteristics and financial performance of deposit money banks in Nigeria. International Journal of Business and Social Science, 7(9).

Adeoye, A. A. (2013). The key challenges of the corporate governance of firms: Empirical evidence from Sub-Saharan African Anglophone (SSAA) Countries. Brunel University London, UK. Retrieved from bura.brunel.ac.uk/bitstream/2438/7654/1/FulltextThesis. pdf

African Corporate Governance Network (ACGN 2015). State of corporate governance in Africa: An overview of 13 Countries. Retrieved from www.afcgn.org

African Development Bank -AfDB. (2015). African Development Bank unveils first-ever study of female board membership in Africa. Retrieved from https://www.afdb.org/en/ news-and-events/african-development-bank-unveils-first-ever-study-of-female-board-m embership-in-africa-14373

Ailemen, I. O., \& Oyero, K. B. L. (2013) .The effect of merger on deposit money banks' performance in the Nigerian banking industry. Journal of Applied Finance \& Banking, $3(4), 105-123$.

Akingunola, R. O., Olusegun, A. A., \& Oluseyi, A. A. (2013). Corporate governance and bank's performance in Nigeria (post - banks consolidation). European Journal of Business and Social Sciences, 2(8), 89-111. Retrieved from http://www.ejbss.com/recent.aspx

Antonakis, J., Bendahan, S., Jacquart, P., \& Lalive, R. (2014) Causality and endogeneity: Problems and solutions. In D. V. Day (Ed.), The Oxford Handbook of Leadership and Organizations. New York: Oxford University Press.

Association of Certified Chartered Accountants-ACCA. (2018). The Governance Lesson: Carillion's Collapse. Retrieved from https://www.accaglobal.com/uk/en/member/ member/accountingbusiness/2018/04/corporate/carillions-collapse.html

Atuahene, R. A. (2016). Corporate governance and financial performance: Evidence from the Ghanian banking sector (University of Bradford e Thesis). Retrieved from https://bradscholars.brad.ac.uk/handle/1054/

Backstrom, L., Huttenlocher, D., Kleinberg, J., \& Lan, X. (2006). Group formation in large social networks. Proceedings of the 12th ACM SIGKDD international conference on Knowledge discovery and data mining (Philadelphia, PA, USA - August 20-23) - KDD '06. p. 44. http://dx.doi.org/10.1145/1150402.1150412

Banff. (2016). Improving governance performance: Rules-based vs principles-based approaches. Retrieved from http://www.banffexeclead.com/AcumenPDF/Governance\% 
20Articles/Leadership\%20Acumen\%2016\%20V10\%20G

Bank of Ghana. (2018). Corporate governance directive 2018: For banks, savings and loans companies, finance houses and financial holding companies. Bank of Ghana. Retrieved from https://www.bog.gov.gh/public-notices/3930-corporate-governance-directive-2018

Banaha, C., \& Hasson, G. (2018). Across the board improvements: Gender diversity and ESG Performance. Harvard Law School Forum on Corporate Governance and Financial Regulation. Retrieved from https://corpgov.law.harvard.edu/

Beck, T., Fuchs, M., Singer, D., \& Witte, M. (2012). Making cross-border banking work for Africa-Brief history of banking in Africa (Brownbridge and Harry, 1998). Retrieved from http://aff.mfw4a.org/fileadmin/data_storage/documents/other-internal-documents/Makin g_Cross-Border

Belhaj, S., \& Mateus, C. (2016). Corporate governance impact on bank performance: Evidence from Europe. Corporate Ownership \& Control, 13(4).

Catalyst. (2018). Quick take: Women in the workforce-United States. Retrieved from https://www.catalyst.org/research/women-in-the-workforce-united-states/

CBN. (2014). Code of corporate governance for banks and discount houses in Nigeria. Retrieved in November 2017 from www.ecgi.org/codes/documents/cg_codes_Nigeria_ 16may2014_en.pdf

Dauda, R. O. S., \& Hawa, A. (2016). Corporate governance and bank performance: A case study of selected commercial banks in Nigeria. Retrieved April 13, 2018, from http://repository.unilag.edu.ng:8080/xmlui/handle/123456789/983

Daumont, R., Le Gall, F., \& Leroux, F. (2004). Banking in Sub-Saharan Africa: What went wrong? IMF WP/04/55. Retrieved from http://citeseerx.ist.psu.edu/viewdoc/download? http://dx.doi.org/doi=10.1.1.528.1619...

Dion, K. L. (2000). From field of forces to multidimensional construct. Group Dynamics: Theory, Research, and Practice, 4, 7-26. http://dx.doi.org/10.1037/1089-2699.4.1.7

FBN (2015). First Bank Nigeria Holdings Plc annual report and accounts 2015: Chairman introduction (p. 105).

FRC. (2019). FRC unveils Nigerian Code of Corporate Governance (NCCG 2018). Retrieved from https://www.financialreportingcouncil.gov.ng

Financial Services Commission Circular Letter- FSC. (2018). National code of corporate governance: Circular letter CL280218. Mauritius. Retrieved from https://www.fscmauritius.org/media/4301/circular-letter-cl28022018.pdf

Flamini, V., McDonald, C., \& Schumacher, L. (2009). The Determinants of commercial bank profitability in Sub-Saharan Africa. IMF Working Paper No. WP/09/15.

FRC. (2019). FRC unveils Nigerian Code of Corporate Governance (NCCG 2018). Retrieved 
from https://www.financialreportingcouncil.gov.ng

García-Izquierdo, L. A., Fernández-Méndez, C., \& Arrondo-García, R. (2018). Gender diversity on boards of directors and remuneration committees: The influence on listed companies in Spain. Frontiers in Psychology. http://dx.doi.org/10.3389/fpsyg.2018.01351

Guest, P. M. (2011). The Impact of board Size on firm performance: Evidence from the UK. European Journal of Finance, 15(4), 385-404. http://dx.doi.org/10.1080/135184708 02466121

Gyamerah, S., \& Agyei, A. (2016). OECD Principles of corporate governance: Compliance among Ghanaian listed companies. International Journal of Advanced Multidisciplinary Research, 3(11).

Hassan, S. U., \& Farouk, M. A. (2014). Board of director's characteristics and performance of listed deposit money banks in Nigeria. Journal of Finance and Bank Management, 2(1), 89-105

Heidrick \& Struggles Board Monitor. (2018). Appointments of women to boards hit record high history of Board Monitor. Retrieved from http://www.heidrick.com/KnowledgeCenter/ Publication/Board_Monitor_2018

Hogg, M. A., \& Williams, K. D. (2000). From I to we: Social identity and the collective self. Group Dynamics: Theory, Research, and Practice, 4, 81-97. http://dx.doi.org/10.1037/1089-2699.4.1.81

Hunt, V., Layton, D., \& Prince, S. (2015). Diversity Matters. McKinsey \& Company. Retrieved from https://assets.mckinsey.com/ /media/857F440109AA4D13A54D9C496D86ED58. ashx

Iacobelli, A. (2017). Determinants of profitability: Empirical evidence from the largest Global banks. Retrieved from www.albany.edu/honorscollege/files/AntonioIacobelli.pdf

International Finance Corporation. (IFC, 2016). Corporate governance: Sub Saharan Africa. Retrieved from https:/www.ifc.org/wps/wcm/connect/bf9aff0047f4dbbdad23fd299ede9 589/CG+AfCGP+Program+Fact+Sheet.pdf

Institute of Directors in Southern Africa- IoDSA. (2016). King IV report. Retrieved from https://www.iodsa.co.za/page/KingIVReport

Jeong, S., \& Harrison, D. A. (2016). Glass breaking, strategy making, and value creating: Meta-analytica outcomes of women as CEO and TMT members. Academy of Management Journal, 60(4). Retrieved from https://journals.aom.org/doi/abs/10.5465/amj.2014.0716

Jhingan, M. L., \& Stephen, J. K. (2009). Managerial Economics (2nd ed.). Delhi, India, Vrinda Publications (P) Ltd.

John, E. I. (2015). Corporate governance and banking sector performance in Nigeria. Nnamdi 
Azikiwe University Awka African Banking \& Finance Review, 2(1).

Josiah, J., Themba, G., \& Matenge, T. M. (2016). Corporate governance in Botswana: Exploring developments and compliance. Botswana Journal of Business, 9(1). Retrieved from http://journals.ub.bw/index.php/bjb/article/view/777

Kantarelis, D. (2007). Theories of the Firm (2nd ed.). Inderscience Publishers, Olney, United Kingdom. Retrieved from http://www.inderscience.com/books/TOF_leaflet.pdf

Kaplan. (2012). Corporate governance: Rules-based versus principles-based approach. Retrieved from http://kfknowledgebank.kaplan.co.uk/KFKB/Wiki\%20Pages/Corporat e\%20governance.aspx

King, M. E. (2016). State of corporate governance in Africa: An overview of 13 countries. Retrieved from https://www.afcgn.org/wp-content/uploads/2016/03/ACGN-CorporateGovernance-Report-Feb-2016.pdf

Kolawole, Y. (2018). New Corporate governance code takes off January 2020-FRC. Retrieved from https://www.vanguardngr.com/2018/06/new-corporate-governance-code-takes-offjanuary-2020-frc/

Konrad, A. M., \& Kramer, V. W. (2006). How many women do boards need? Harvard Business Review. Retrieved from https://hbr.org/2006/12/how-many-women-do-boardsneed

Kosmidou, K., Tanna, S., \& Pasiouras, F. (2012). Determinants of profitability of domestic UK commercial banks: Panel evidence from the period 1995-2002. Paper (series no. RP08-4) presented at 37th Annual Conference of the Money, Macro and Finance Research Group, held 1-3 Sept 2005, Rethymno, Crete. Retrieved from http://www.york.ac.uk/res/mmf/conference2005.htm

Kota, H. (2019, February 13). From tokenism to critical mass. The Pioneer. Retrieved from https://www.dailypioneer.com/2019/columnists/from-tokenism-to-critical-mass.html

KPMG. (2017). Africa's economy continues to develop under robust corporate governance Principles. Retrieve from https://home.kpmg.com/xx/en/home/media/press-releases/ 2017/06/africa-grows-under-

Loop, P., \& DeNicola, P. (2019, February 18). You've committed to increasing gender diversity on your board: Here's how to make it happen. Harvard Business Review.

Love, I., (2010). Corporate governance and performance around the world: What we know and what we don't. The World Bank Research Observer, 26(1), 42-70. Retrieved from https://doi.org/10.1093/wbro/lkp030

Marris, R. (1964). The economic theory of "managerial" capitalism. Glencoe, IL: Free Press of Glencoe.

Mauritius Financial Services Commission Circular Letter. (FSC, 2018). National code of corporate Governance. FSC Circular Letter No. CL280218 
McKinsey. (2016). Board perspective: A collection of McKinsey insights focusing on board of directors. Retrieved from https://www.mckinsey.com/ /media/mckinsey/.../the-boardperspective.ashx

Michin, \& Kelly. (2018). Corporate Governance: Corporate Botswana is ready for corporate governance. Retrieved from https://minchinkelly-bw.com/2018/10/15/corporatebotswana-is-

Milkman, K., Akinola, M., \& Chang, E. (2018, November 3). On the board, 'twokenism' is the new tokenism. Washington Post. Retrieved from https//www.washingtonpost.com

Mitnick, B. M. (2006). Origin of the theory of agency: An account by one of the theory Originators, Katz Graduate School of Business, University of Pittsburgh. Retrieved from http://www.pitt.edu/ mitnick/agencytheory/agencytheoryoriginrev11806r.htm

Mitnick, B. M. (1973). Fiduciary rationality and public policy: The theory of agency and some consequences. Paper presented at the 1973 Annual Meeting of the American Political Science Association, New Orleans, LA. In Proceedings of the APSA, 1973 (formerly available from Xerox University Microfilms and, later, UMI Serials).

Mlachila, M., Park, S. G., \& Yabara, M. (2013). Banking in Sub-Saharan Africa:The macroeconomic context. IMF African Department. Retrieved from https://www.imf.org/external/pubs/ft/dp/2013/afr1303.pdf

Moyo, J., Nandwa, B., Oduor, J., \& Simpasa, J. (2014). Financial sector reforms, competition and banking system stability in Sub-Saharan Africa. Being Paper presented at the joint RES-SPR Conference on "Macroeconomic Challenges Facing Low-Income Countries" Hosted by the International Monetary Fund with support from the UK Department of International Development (DFID) Washington, DC-January 30-31.

Mulenwa Wordpress. (2016). The Kenyan code of corporate governance. Retrieved from https://mulenwa.wordpress.com/2016/10/24/code-of-corporate-governance-2016/

Mungly, Y., Seetanah, B., Seetah, K., Babajee, R. B., Maraye, N., \& Ramdhany, N. G. (2016). Determinants of Mauritian commercial banking profitability. Proceedings of the Fifth Asia-Pacific Conference on Global Business, Economics, Finance and Social Sciences (AP16Mauritius Conference) Port Louis, Mauritius.

Narwal, P. K., \& Pathneja, S. (2015). Determinants of productivity and profitability of Indian banking sector: A Comparative study. Eurasian Journal of Business and Economics, 8(16), 35-58. http://dx.doi.org/10.17015/ejbe.2015.016.03

Navitidad, I. (2015). Where are the women: Inclusive boardrooms in Africa's top listed companies. African Development Bank. Retrieved from www.afdb.org

Nodeh, F. M., Anuar, M. A., Suresh, R., \& Raftnia, A. A. (2016). The Effect of board structure on banks financial performance by moderating firm Size. Mediterranean Journal of Social Sciences, 7(1). 
Nwaubani, A. N. (2019). Appointment of directors and performance of deposit money banks in Sub Saharan Africa: Do we need more executive or non-executive directors? Journal of Empirical Studies, 6(1), 1-18. http://dx.doi.org/10.18488/journal.66.2019.61.1.18

Nwaubani, A. N., \& Idika, J. E. (2019). Effect of Corporate Governance on Performance of Deposit Money Banks in Sub Saharan Africa: The Gender Diversity Debate. Journal of Banking and Finance, 3(3). A Publication of Department of Banking and Finance, Rivers State University.

Nwaubani, A. N., \& Ezeudu, J. I. (2015). Mergers and acquisitions: An approach for addressing crisis of confidence in the Nigerian banking sector. ESUT Journal of Accountancy, 6(2), 139-156.

Ogunbiyi, S. S., \& Ihjirika, P. O. (2014). Interest rates and deposit money banks' profitability nexus: The Nigerian experience. Arabian Journal of Business and Management Review (OMAN Chapter), 3(11).

O'Kelley III, R., Goodman, A., \& Martin, M. (2017). Global and regional trends in corporate governance for 2018. Russell \& Reynolds Associates Report on Corporate. Retrieved from www.russellreynolds.com

Otchere, I., \& Senbet, L. (2017). Financial sector development in Africa-an overview. Financial sector development in Africa-an overview / Review of Development Finance, 7, 1-5. Retrieved from http://ac.els-cdn.com/S1879933717300544/1-s2.0-S187993371730 0544

Panda, B., \& Leepsa, N. M. (2017). Agency theory: Review of theory and evidence on problems and perspectives. Indian Journal of Corporate Governance, 10(1), 74-95.

Perryer, S. (2018). The essential group dynamics checklist. Retrieved from https://www.perkbox.com/uk/resources/blog/the-essential-group-dynamics-checklist

Proshare. (2016). Financial reporting council (FRC) of Nigeria: National code of corporate governance 2016. Retrieved from https://www.proshareng.com/admin/upload/reports/ PrivateSectorCode.pdf

Romano, G., Ferretti, P., \& Quirici, M. C. (2012). Corporate governance and performance in Italian banking groups. Managerial Auditing Journal, 27(7), 622-638.

Rekhi, S. (n. d.). Top 3 theories of firm (with diagram): Marris's model of managerial Enterprise. Retrieved from www.economicsdiscussion.net/firm/top-3-theories-of-firmwith-diagram/19519

Soledad, C., Vinsrygg, K., Summerfield, A., \& Reingold, J. (2018). Who is really on board? Egon Zehnder 2018 Global Board Diversity Tracker. Retrieved from https://www.egonzehnder.com/global-board-diversity-tracker

Smith, P. The Gender 'Diversity' Debate is Pointless! Paul Smith Leadership. Retrieved from https://www.theoutperformer.co/post/the-gender-diversity-debate-is-pointless-paul-smith 


\section{Macrothink}

Staley, O. (2016). You know those quotas for female board members in Europe? They're Working. Retrieved from https://qz.com/674276/you-know-those-quotas-for-femaleboard-members-in-europe-

Terjesen, S., Sealy, R. \& Singh, V. (2009). Women directors on corporate boards: A review and research agenda. Corporate Governance: An International Review, 17(3), 320-337.

Tomczak, D. A. (2016). Gender equality policies and their outcomes in Norway. Zarzadzanie Publiczne, 4(36), 379-391. http://dx.doi.org/10.4467/20843968ZP.17.032.6041

Torres-Reyna, O. (2007). Panel data analysis: Fixed and random effects using Stata (v. 4.2). Princeton University, New Jersey USA. Retrieved from http://dss.princeton.edu/training/...

Veklenko, K. (2016). The Impact of board composition on the firm's performance in Continental Europe. University of Twente, The Faculty of Behavioural, Management and Social Siences. Retrieved from https://essay.utwente.nl/70171/1/Veklenko_BA_BMS.pdf

Wasserman, N. (2006) Stewards, agents, and the founder discount: Executive compensation in new ventures. Academy of Management Journal, 49(5), 960-976.

Wharton. (2017). Does gender diversity on boards really boost company performance? Wharton University, Pennsylvania. Retrieved from http://knowledge.wharton.upenn.edu/ article/will-gender-diversity-boards-really-boost-company-performance/

Yilmaz, C., \& Buyuklu, A. H. (2016). Impact corporate governance on firm performance: Turkey case with a panel data analysis. Eurasian Journal of Economics and Finance, 4(1), 56-72.

\section{Copyright Disclaimer}

Copyright for this article is retained by the author(s), with first publication rights granted to the journal.

This is an open-access article distributed under the terms and conditions of the Creative Commons Attribution license (http://creativecommons.org/licenses/by/3.0/). 